\title{
Rupture process of the 2004 great Sumatra-Andaman earthquake estimated from tsunami waveforms
}

\author{
Yuichiro Tanioka $^{1}$, Yudhicara ${ }^{2,6}$, Tomohiro Kususose ${ }^{1}$, S. Kathiroli ${ }^{3}$, Yuichi Nishimura ${ }^{1}$, Sin-Iti Iwasaki ${ }^{4}$, and Kenji Satake ${ }^{5}$ \\ ${ }^{1}$ Institute of Seismology and Volcanology, Hokkaido University, N10W8 Kita-ku, Sapporo 060-0810, Japan \\ ${ }^{2}$ Department of Geophysics and Meteorology, Bandung Institute of Technology, Jalan Ganeca 10, Bandung 40132, Indonesia \\ ${ }^{3}$ National Institute of Ocean Technology, NIOT Campus, Velachery-Tambaram Main road, Pallikaranai, Chennai, 601302, India \\ ${ }^{4}$ National Research Institute for Earth Science and Disaster Prevention, 3-1 Tennodai, Tsukuba 305-0006, Japan \\ ${ }^{5}$ Active Fault Research Center, National Institute of Advanced Industrial Science and Technology, \\ Site C7 1-1-1 Higashi, Tsukuba 305-8567, Japan \\ ${ }^{6}$ Marine Geological Institute, Jl. Dr. Junjunan No. 236 Bandung 40174, Indonesia
}

(Received July 28, 2005; Revised December 5, 2005; Accepted December 13, 2005; Online published February 17, 2006)

\begin{abstract}
Rupture process of the 2004 Sumatra-Andaman earthquake is estimated using tsunami waveforms observed at tide gauges and the coseismic vertical deformation observed along the coast. The average rupture speed of the 2004 Sumatra-Andaman earthquake is estimated to be $1.7 \mathrm{~km} / \mathrm{s}$ from tsunami waveform analysis. The rupture extends about $1200 \mathrm{~km}$ toward north-northwest along the Andaman trough. The largest slip of $23 \mathrm{~m}$ is estimated on the plate interface off the northwest coast in the Aceh province in Sumatra. Another large slip of $21 \mathrm{~m}$ is also estimated on the plate interface beneath the north of Simeulue Island in Indonesia. The other large slip of $10-15 \mathrm{~m}$ is estimated on the plate interface near Little Andaman and Car Nicobar Inlands. The total seismic moment is calculated to be $7.2 \times 10^{22} \mathrm{Nm}(\mathrm{Mw} 9.2)$ which is similar to the other studies using seismic waves (Park et al., 2005; Ammon et al., 2005).
\end{abstract}

Key words: 2004 Sumatra-Andaman tsunami, numerical simulation, tsunami waveform inversion, slip distribution.

\section{Introduction}

The Sumatra-Andaman earthquake on 26 December 2004 was the largest in the world since the 1964 great Alaska earthquake. The aftershock area extended from northwest of Sumatra Island to Andaman Islands (Fig. 1). The total length of the aftershock area was over $1200 \mathrm{~km}$. The mechanism of the earthquake according to the Harvard CMT catalog indicated thrust type faulting (strike $=329^{\circ}$, $\operatorname{dip}=8^{\circ}$, rake $=110^{\circ}$ ). This suggests that the earthquake was an underthrusting plate boundary event due to the subduction of the Indian-Australian plate beneath the Eurasian plate.

The teleseismic waveform study by Ammon et al. (2005) showed that the rupture expanded at a speed of about 2.5 $\mathrm{km} / \mathrm{s}$ toward the north-northwest, extended 1200 to 1300 $\mathrm{km}$ along the Andaman trough. However, large slip occurred along a $600 \mathrm{~km}$ segment of the plate boundary offshore of northwestern Sumatra and the southern Nicobar islands. Slip was less in the northern part. They also suggested that the some slip in the northern 400 to $500 \mathrm{~km}$ of the aftershock zone have occurred on a time scale beyond the seismic band. Earth's free oscillation study by Park et al. (2005) showed that the seismic moment of the earthquake was $6.5 \times 10^{22} \mathrm{Nm}(\mathrm{Mw} 9.15)$ with rupture duration of 600 seconds. Lay et al. (2005) also indicated that addi-

Copyright (c) The Society of Geomagnetism and Earth, Planetary and Space Sciences (SGEPSS); The Seismological Society of Japan; The Volcanological Society of Japan; The Geodetic Society of Japan; The Japanese Society for Planetary Sciences; TERRAPUB tional slow slip occurred in the north over a time scale of 50 minutes or longer.

In this paper, the slip distribution of the 2004 SumatraAndaman earthquake is estimated using tsunami waveforms observed at tide gauges and the coseismic vertical deformation observed along the coast. Our results are compared with those estimated using the seismological analyses (Park et al., 2005; Ammon et al., 2005).

\section{Data}

Tsunami waveforms observed at 5 tide gauge stations are used to estimate the slip distribution of the 2004 great Sumatra-Andaman earthquake. Those tide gauges include two tide gauges at Sibolga and Belawan in Indonesia operated by the Geodesy and Geodynamic Center in Indonesia, a tide gauge at Colombo operated by the National Aquatic Resources Agency in Sri Lanka, a tide gauge at Vishakhapatnam operated by the National Geophysical Research Institute in India, an acoustic tide gauge at Port Blair operated by the National Institute of Ocean Technology in India (Fig. 1). Those five tide gauge are located relatively close to the source area and also surround the source area.

The vertical crustal deformation due to the earthquake is used to constrain the fault model. Two international teams surveyed the northern Sumatra region in Indonesia in January, 2005. One team in Aceh province (Kawata et al., 2005) measured the vertical coseismic deformation in the Banda-Aceh city by comparing the previous geodetic measurement conducted in 2002 and the measurements in 2005. 


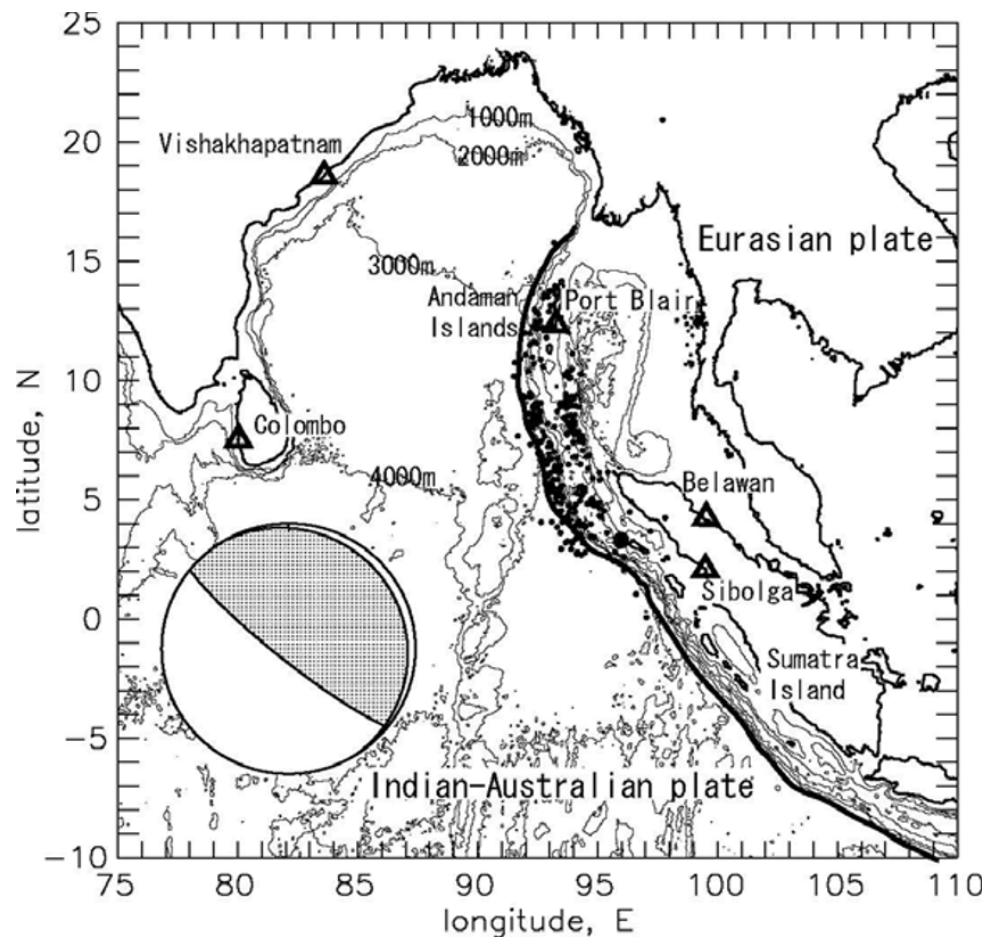

Fig. 1. Map around the source area of the 2004 Sumatra-Andaman earthquake. Triangles show tide gauges where tsunami waveforms are recorded. Dots represent the aftershock distribution. The focal mechanism of the earthquake from the Harvard CMT catalog is also shown.

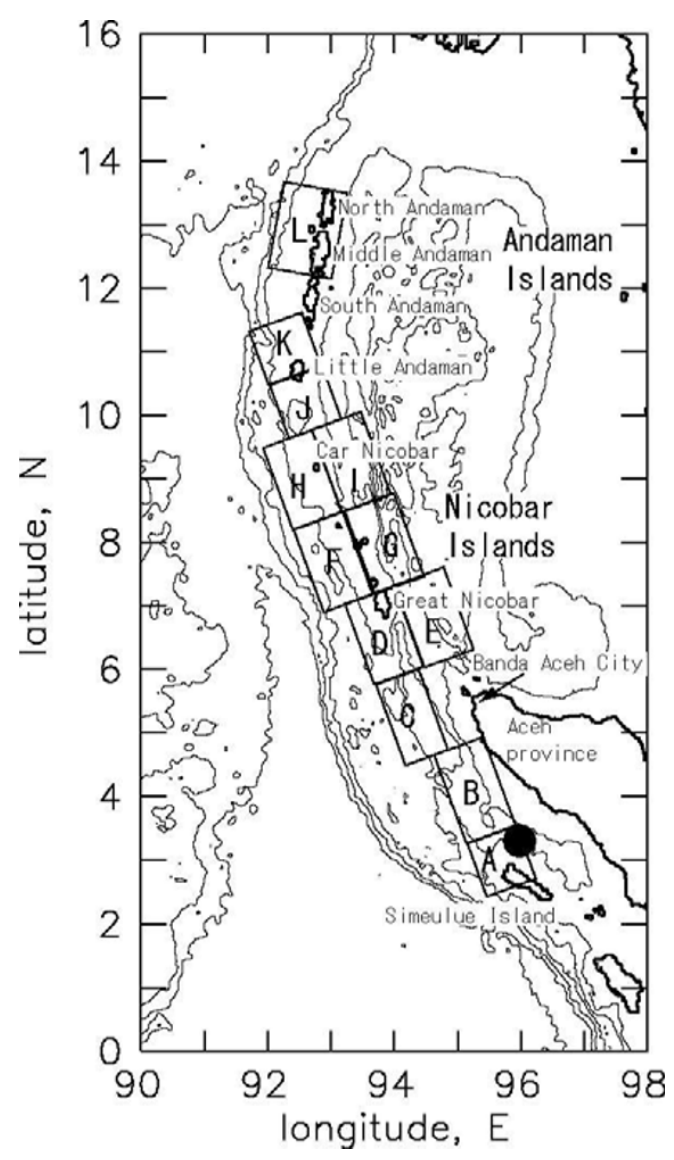

Fig. 2. Map near the source area of the 2004 Sumatra-Andaman earthquake. Rectangles show subfaults used to estimate slip amounts by the tsunami waveform inversion. A solid circle shows the epicenter of the earthquake.
The results indicated that the subsidence of $20-60 \mathrm{~cm}$ occurred in Banda Aceh city (Fig. 2). Along the northwest coast of the Aceh province, the coseismic subsidence was more than $1 \mathrm{~m}$ which was measured using the submerged trees. The other international team surveyed the coseismic deformation in Simeulue Island located near the epicenter of the earthquake (Kaistrenko et al., 2006). The team found that the northern end of Simeulue Island (Fig. 2) was uplifted about $1.5 \mathrm{~m}$, but the southern part of the Island was subsided a few tens of centimeters. Malik and Murty (2005) surveyed the coseismic deformation in Andaman Islands and Nicobar Islands, India. They showed that the most of the coast around the Andaman Islands was uplifted, but only the coast along South Andaman Island near Port Blair was subsided. They also showed that the coast around the Nicobar Inlands was subsided due to the earthquake. Tobita $e t$ al. (2005) also determined the coastal uplifts or subsidence due to the earthquake along the Andaman and Nicobar Islands using satellite images of the coast before and after the earthquake. Their results are consistent with the other measurements surveyed by Malik and Murty (2005). However, both Malik and Murty (2005) and Tobita et al. (2005) did not estimate the amount of the uplifts or subsidence. The acoustic tide gauge at Port Blair, operated by the National Institute of Ocean Technology in India, clearly showed that the coseismic subsidence of $0.9 \mathrm{~m}$ occurred at the Port Blair.

\section{Tsunami Inversion Method to Estimate the Slip Distribution}

The tsunami waveform inversion (Satake, 1989; Johnson, 1998; Tanioka and Satake, 2001) is used to estimate the slip distribution of the 2004 Sumatra-Andaman earthquake. The fault area of the earthquake is divided into several smaller 
The average rupture speed of $0.9 \mathrm{~km} / \mathrm{s}$

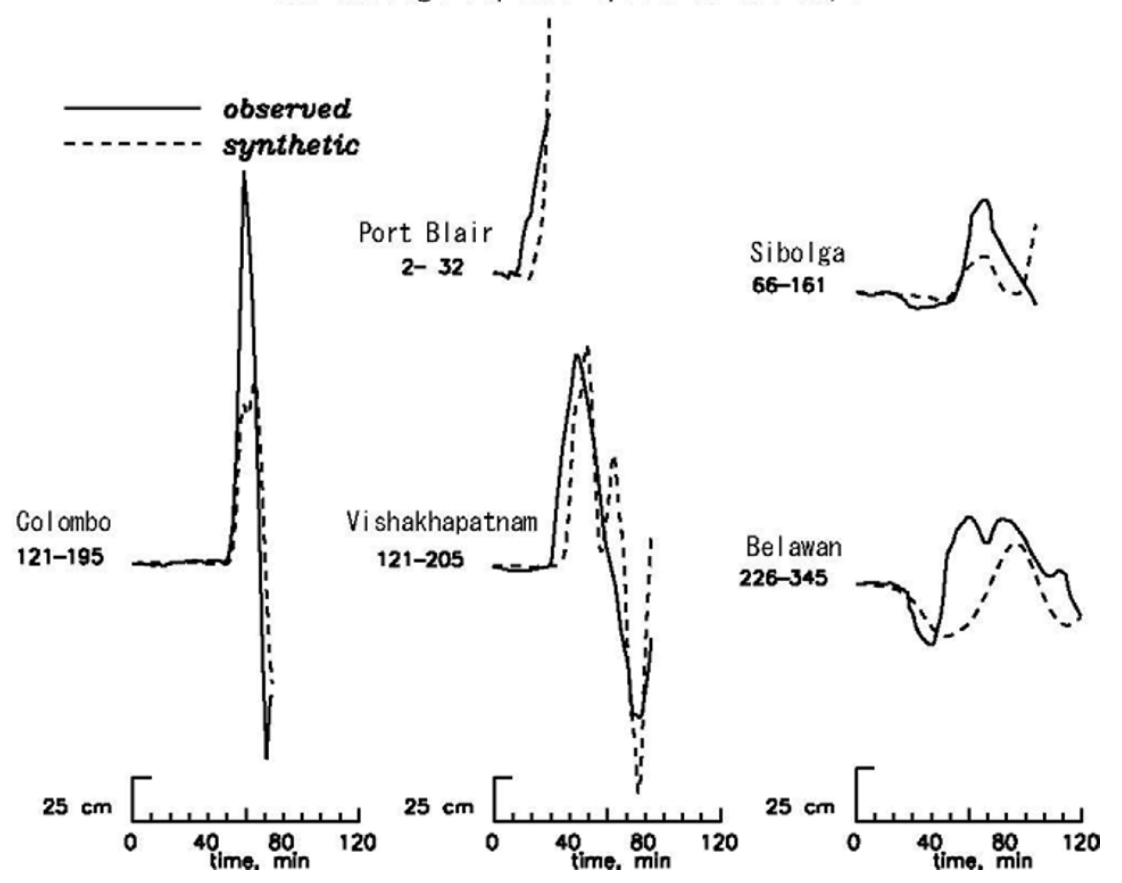

Fig. 3. Comparison of the observed (solid lines) and computed (dashed lines) tsunami waveforms at tide gauges for Model A which has an average rupture speed of $0.9 \mathrm{~km} / \mathrm{s}$. Numbers below the tide gauge name indicate the time (in minutes) after the earthquake origin time.

The average rupture speed of $1.7 \mathrm{~km} / \mathrm{s}$

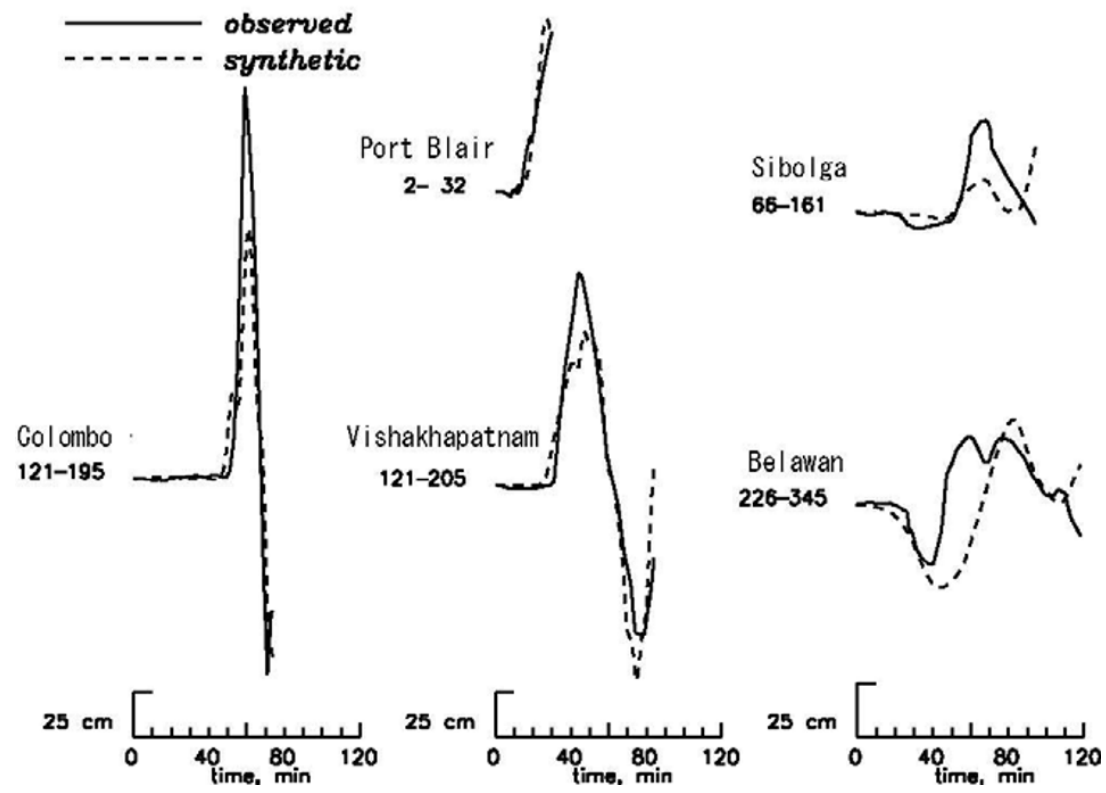

Fig. 4. Comparison of the observed (solid lines) and computed (dashed lines) tsunami waveforms at tide gauges for Model B which has an average rupture speed of $1.7 \mathrm{~km} / \mathrm{s}$. Numbers below the tide gauge name indicate the time (in minutes) after the earthquake origin time.

subfaults. The tsunami waveform at each tide gauge station is computed for each subfault. The result is one Green's function for each subfault for each tide gauge station. The slip amount on each subfault is estimated from the observed tsunami waveforms using the inversion technique.

To calculate the tsunami Green's functions, the linear long wave equations with the Coriolis force are solved us- ing finite-difference calculations on a staggered grid system (Johnson, 1998). The grid size is $1 \mathrm{~min}$. of arc (about 1.8 $\mathrm{km})$ in deep water; a finer grid (20 sec of arc) is used around the tide gauge stations. The time step for the computation is $5 \mathrm{~s}$ to satisfy a stability condition. The initial condition for tsunami propagation is the coseismic ocean bottom vertical displacement, which is computed using the equations 


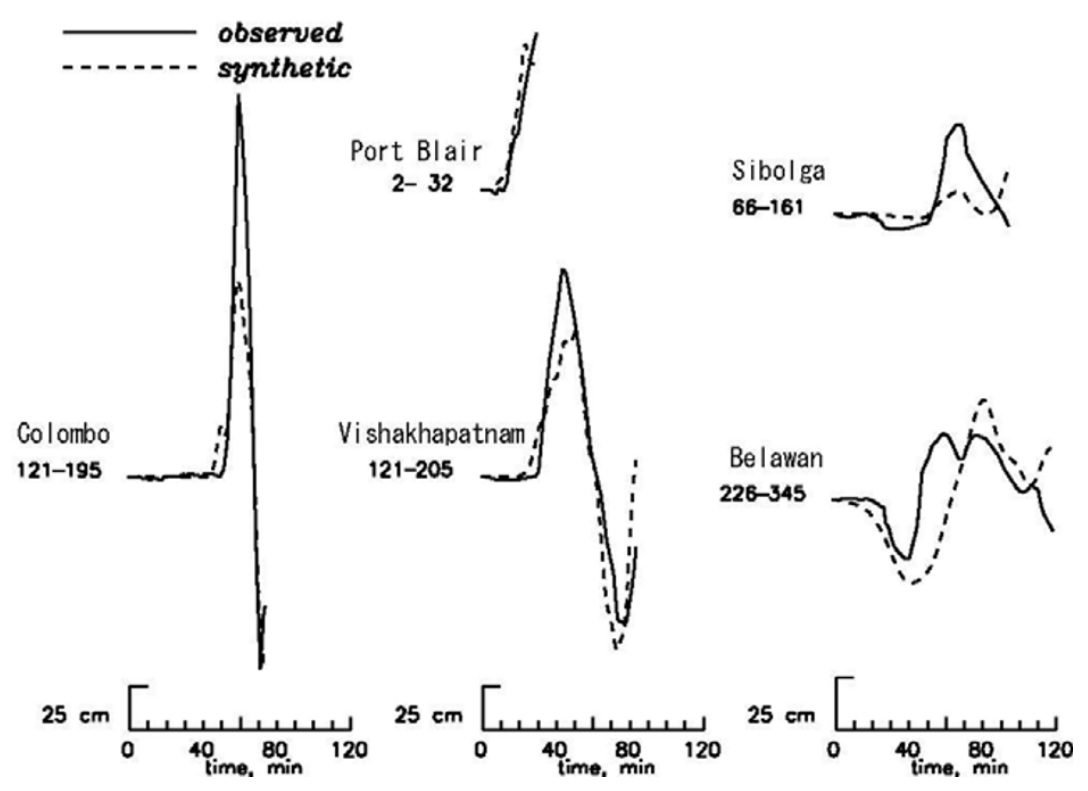

Fig. 5. Comparison of the observed (solid lines) and computed (dashed lines) tsunami waveforms at tide gauges for Model $\mathrm{C}$ which has an average rupture speed of $2.5 \mathrm{~km} / \mathrm{s}$. Numbers below the tide gauge name indicate the time (in minutes) after the earthquake origin time.

The average rupture speed of $3.4 \mathrm{~km} / \mathrm{s}$

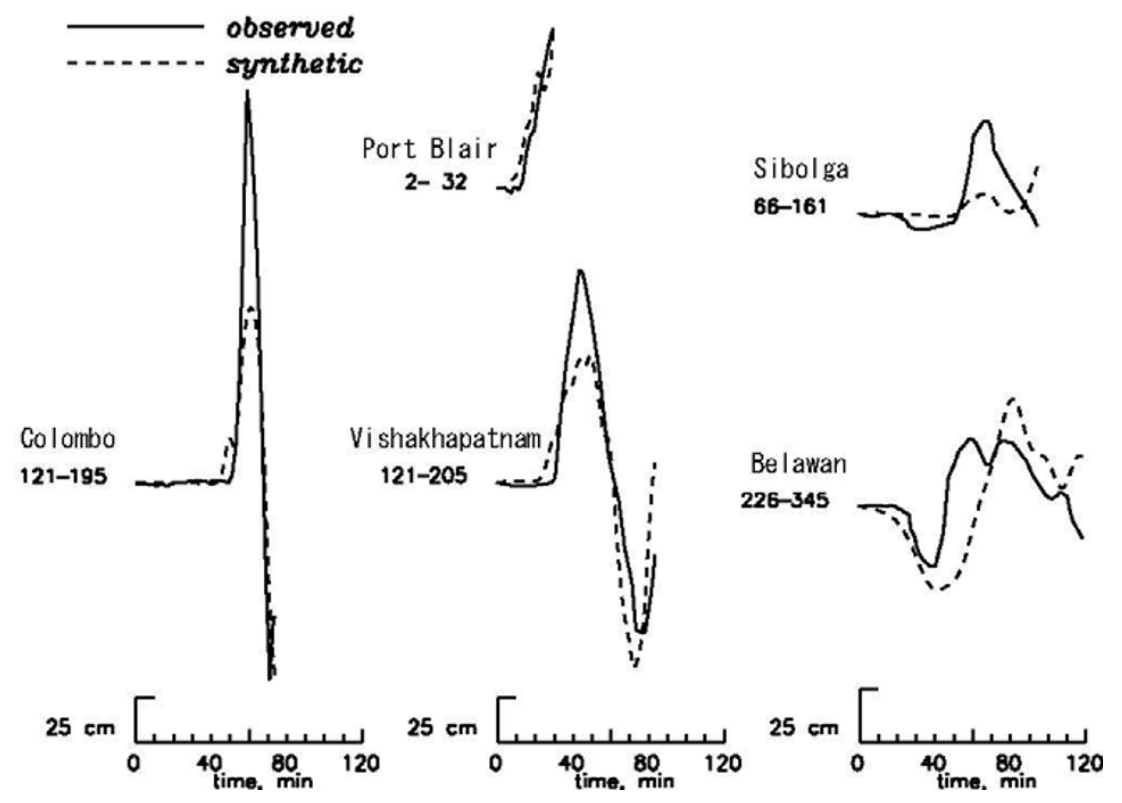

Fig. 6. Comparison of the observed (solid lines) and computed (dashed lines) tsunami waveforms at tide gauges for Model D which has an average rupture speed of $3.4 \mathrm{~km} / \mathrm{s}$. Numbers below the tide gauge name indicate the time (in minutes) after the earthquake origin time.

of Okada (1985) from the fault parameters described in the following section. The rise time of the tsunami initial wave is assumed to be 2 minutes. For error analysis, the jackknife technique (Tichelaar and Ruff, 1989) is applied.

\section{Fault Models for the Tsunami Inversion}

The source area of the 2004 Sumatra-Andaman earth- quake is divided into 12 subfaults (Fig. 2). The subfault $\mathrm{A}$ is located at the plate interface beneath the north of Simeulue Island as shown in Fig. 2 to explain the uplift of the northern part of Simeulue Island and the subsidence of the southern part of the island. The subfault $\mathrm{C}$ is located off the west coast of the Aceh province in Sumatra Island to explain the subsidence along the west coast of the Aceh province. 
Table 1. Parameters of subfaults.

\begin{tabular}{|c|c|c|c|c|c|c|c|}
\hline \multirow[t]{2}{*}{ Subfault } & \multicolumn{2}{|c|}{ 1) Location } & \multirow{2}{*}{$\begin{array}{c}\text { Length } \\
(\mathrm{km})\end{array}$} & \multirow{2}{*}{$\begin{array}{l}\text { Width } \\
(\mathrm{km})\end{array}$} & \multirow{2}{*}{$\begin{array}{c}\text { Depth of top } \\
\text { edge }(\mathrm{km})\end{array}$} & \multirow{2}{*}{$\begin{array}{c}\text { Strike } \\
\text { (degree) }\end{array}$} & \multirow{2}{*}{$\begin{array}{l}\text { Dip angle } \\
\text { (degree) }\end{array}$} \\
\hline & Latitude & Longitude & & & & & \\
\hline A & $2^{\circ} 22^{\prime}$ & $95^{\circ} 33^{\prime}$ & 100 & 100 & 10 & 340 & 10 \\
\hline B & $3^{\circ} 14^{\prime}$ & $95^{\circ} 14^{\prime}$ & 160 & 100 & 10 & 340 & 10 \\
\hline $\mathrm{C}$ & $4^{\circ} 27^{\prime}$ & $94^{\circ} 15^{\prime}$ & 150 & 90 & 10 & 340 & 10 \\
\hline $\mathrm{D}$ & $5^{\circ} 44^{\prime}$ & $93^{\circ} 48^{\prime}$ & 150 & 100 & 10 & 340 & 10 \\
\hline $\mathrm{E}$ & $6^{\circ} 00^{\prime}$ & $94^{\circ} 34^{\prime}$ & 150 & 100 & 27 & 340 & 10 \\
\hline $\mathrm{F}$ & $6^{\circ} 52^{\prime}$ & $92^{\circ} 56^{\prime}$ & 150 & 100 & 5 & 340 & 10 \\
\hline G & $7^{\circ} 08^{\prime}$ & $93^{\circ} 42^{\prime}$ & 150 & 100 & 22 & 340 & 10 \\
\hline $\mathrm{H}$ & $8^{\circ} 10^{\prime}$ & $92^{\circ} 28^{\prime}$ & 150 & 100 & 5 & 340 & 10 \\
\hline I & $8^{\circ} 26^{\prime}$ & $93^{\circ} 14^{\prime}$ & 150 & 100 & 22 & 340 & 10 \\
\hline $\mathrm{J}$ & $9^{\circ} 37^{\prime}$ & $92^{\circ} 24^{\prime}$ & 100 & 110 & 10 & 340 & 10 \\
\hline $\mathrm{K}$ & $10^{\circ} 27^{\prime}$ & $92^{\circ} 05^{\prime}$ & 150 & 110 & 10 & 340 & 3 \\
\hline $\mathrm{L}$ & $12^{\circ} 21^{\prime}$ & $92^{\circ} 00^{\prime}$ & 100 & 1125 & 5 & 10 & 17 \\
\hline
\end{tabular}

\footnotetext{
1) location of the southwest corner of each subfault.
}

Table 2. Slip distribution for four rupture models.

\begin{tabular}{|c|c|c|c|c|c|c|c|c|}
\hline \multirow[b]{2}{*}{ Subfault } & \multicolumn{2}{|c|}{ Model A $(0.9 \mathrm{~km} / \mathrm{s})$} & \multicolumn{2}{|c|}{ Model B $(1.7 \mathrm{~km} / \mathrm{s})$} & \multicolumn{2}{|c|}{ Model C $(2.5 \mathrm{~km} / \mathrm{s})$} & \multicolumn{2}{|c|}{ Model D $(3.4$ km/s) } \\
\hline & $\begin{array}{c}\text { Initial } \\
\text { rupture } \\
\text { time } \\
\text { (min.) }\end{array}$ & $\begin{array}{l}\text { Slip } \\
\text { (m) }\end{array}$ & $\begin{array}{c}\text { Initial } \\
\text { rupture } \\
\text { time } \\
\text { (min.) }\end{array}$ & $\begin{array}{l}\text { Slip } \\
\text { (m) }\end{array}$ & $\begin{array}{c}\text { Initial } \\
\text { rupture } \\
\text { time } \\
(\min .)\end{array}$ & $\begin{array}{l}\text { Slip } \\
\text { (m) }\end{array}$ & $\begin{array}{c}\text { Initial } \\
\text { rupture } \\
\text { time } \\
(\min .)\end{array}$ & $\begin{array}{l}\text { Slip } \\
\text { (m) }\end{array}$ \\
\hline $\mathrm{A}$ & 0 & $24.4 \pm 5.3$ & 0 & $21.1 \pm 5.0$ & 0 & $14.6 \pm 4.9$ & 0 & $12.7 \pm 5.2$ \\
\hline B & 2 & $0.0 \pm 0.6$ & 1 & $0.0 \pm 0.0$ & 1 & $0.0 \pm 0.0$ & 0 & $0.0 \pm 0.0$ \\
\hline $\mathrm{C}$ & 3 & $17.2 \pm 5.6$ & 1 & $22.9 \pm 6.7$ & 1 & $21.1 \pm 8.5$ & 1 & $24.3 \pm 8.3$ \\
\hline $\mathrm{D}$ & 6 & $1.5 \pm 3.1$ & 3 & $4.2 \pm 3.1$ & 2 & $4.4 \pm 3.1$ & 2 & $1.2 \pm 2.8$ \\
\hline $\mathrm{E}$ & 6 & $5.6 \pm 1.3$ & 3 & $9.6 \pm 1.3$ & 2 & $11.0 \pm 1.3$ & 2 & $11.2 \pm 1.4$ \\
\hline $\mathrm{F}$ & 10 & $15.4 \pm 3.1$ & 5 & $5.1 \pm 2.7$ & 3 & $0.0 \pm 1.0$ & 3 & $0.0 \pm 1.7$ \\
\hline G & 10 & $0.0 \pm 0.0$ & 5 & $0.0 \pm 0.0$ & 3 & $0.0 \pm 0.0$ & 3 & $0.0 \pm 0.0$ \\
\hline $\mathrm{H}$ & 14 & $15.9 \pm 2.7$ & 7 & $11.2 \pm 0.9$ & 5 & $9.9 \pm 1.4$ & 4 & $8.4 \pm 1.8$ \\
\hline I & 14 & $0.0 \pm 0.0$ & 7 & $13.9 \pm 2.6$ & 5 & $20.0 \pm 1.9$ & 4 & $21.1 \pm 2.1$ \\
\hline $\mathrm{J}$ & 18 & $0.0 \pm 2.0$ & 8 & $14.5 \pm 2.1$ & 6 & $11.5 \pm 1.7$ & 4 & $10.5 \pm 1.9$ \\
\hline $\mathrm{K}$ & 20 & $21.4 \pm 3.5$ & 10 & $7.3 \pm 0.4$ & 7 & $6.2 \pm 0.3$ & 5 & $5.2 \pm 0.3$ \\
\hline $\mathrm{L}$ & 24 & $1.7 \pm 1.0$ & 12 & $1.1 \pm 0.3$ & 8 & $0.2 \pm 0.3$ & 6 & $0.0 \pm 0.2$ \\
\hline $\begin{array}{c}\text { RMS } \\
\text { variance } \\
\text { reduction }\end{array}$ & & & & & & & & \\
\hline
\end{tabular}

This subfault represents the largest slip area estimated using the seismological data by Ammon et al. (2005). The subfault $\mathrm{K}$ is located off the southwest of South Andaman Island as shown in Fig. 2 in order to explain the subsidence near Port Blair. The subfault L is located beneath the North and Middle Andaman Islands to explain the uplift of the Islands. The other eight subfaults are located between the above subfaults to cover the aftershock area of the 2004 Sumatra-Andaman earthquake (Fig. 2). The location and size of each subfault are shown in Table 1. The depth of the upper most edge, strike and dip angle of each subfault are also shown in Table 1. The depth of each subfault is chosen to locate the subfaults along the plate interface of the rupture area smoothly. The rake is fixed to be 90 degree for all subfaults. The dip angles of subfaults $\mathrm{K}$ and $\mathrm{L}$ are slightly different from those of the other subfaults in order to well explain the coseismic subsidence near the Port Blair and uplift of North and Middle Andaman Islands.

The seismological analysis showed that the rupture of the earthquake propagated from south to north at a speed of 2.5 $\mathrm{km} / \mathrm{s}$ (Ammon et al., 2005). Because the rupture extended about $1200 \mathrm{~km}$ from the epicenter, the speed of the rupture should affect the tsunami waveforms. We vary the initial rupture time for each subfault. For model A, the average rupture speed of $0.9 \mathrm{~km} / \mathrm{s}$ is assumed, and the initial rupture time for each subfault is shown in Table 2. For model $\mathrm{B}, \mathrm{C}$ and $\mathrm{D}$, the average rupture speed is assumed to be $1.7 \mathrm{~km} / \mathrm{s}, 2.5 \mathrm{~km} / \mathrm{s}$ and $3.4 \mathrm{~km} / \mathrm{s}$, respectively. The initial 


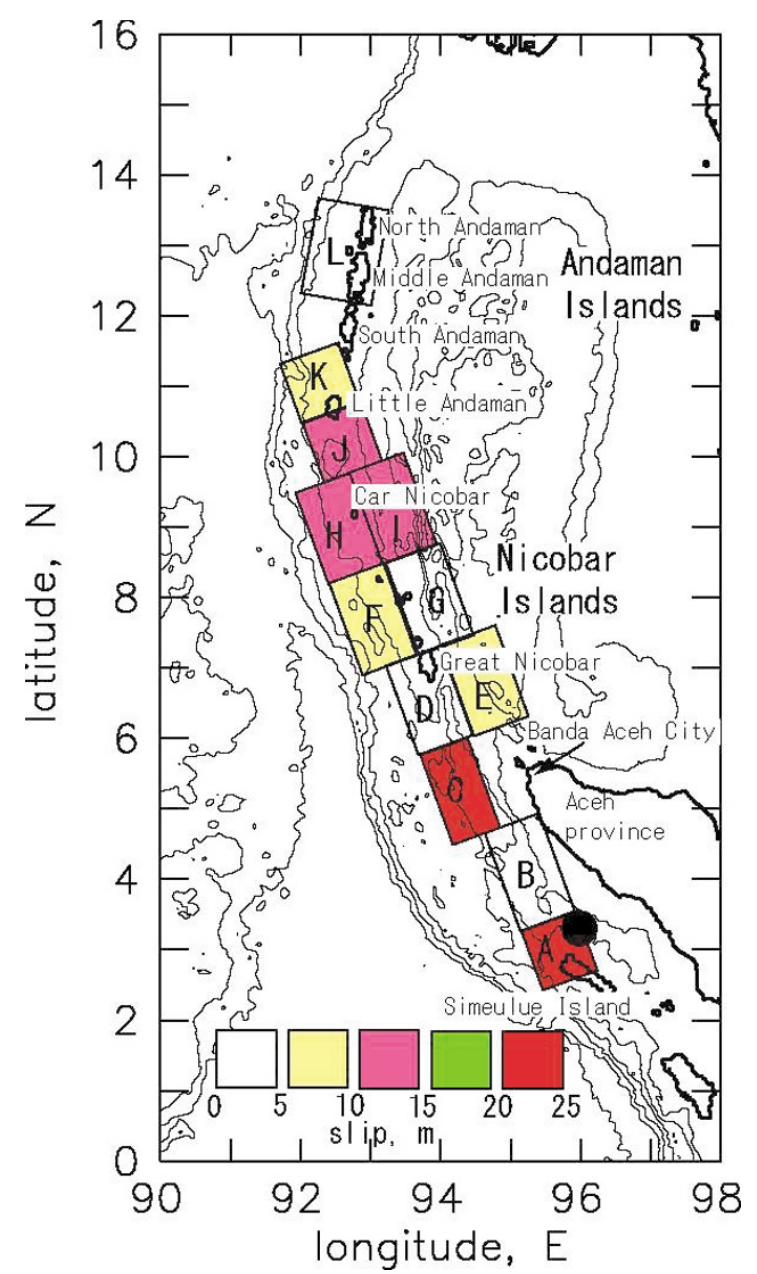

Fig. 7. Coseismic slip distribution of the 2004 Sumatra-Andaman estimated by the tsunami waveform inversion for Model $\mathrm{B}$ which has an average rupture speed of $1.7 \mathrm{~km} / \mathrm{s}$. A solid circle shows the epicenter of the earthquake.

rupture times of subfaults for three models are also shown in Table 2.

\section{Slip Distribution}

The results of the tsunami inversions for four rupture models, Model A, B, C and D, are shown in Table 2. The root mean square (RMS) variance reductions after the inversion for the rupture models, Model A, B, C and D, are $57.4 \%, 72.4 \%, 69.4 \%$ and $66.1 \%$, respectively. The computed tsunami waveforms from the Model B, of which the average rupture speed is $1.7 \mathrm{~km} / \mathrm{s}$, explain the observed tsunami waveforms better than those from the other three models. In Figs. 3, 4, 5 and 6, the observed and computed tsunami waveforms for the three rupture models are compared. The large first wave at Colombo is better explained by the computed wave from Model B (Fig. 4) than that from the other three models, Model A, C and D, (Figs. 3, 5 and 6). The tsunami arrival times at Port Blair and Vishakhapatnam are also better explained by the computed wave from Model B than that from the other three.

Figure 7 shows the slip distribution of the earthquake estimated using the tsunami waveform inversion from Model $\mathrm{B}$, of which the average rupture speed is $1.7 \mathrm{~km} / \mathrm{s}$. The

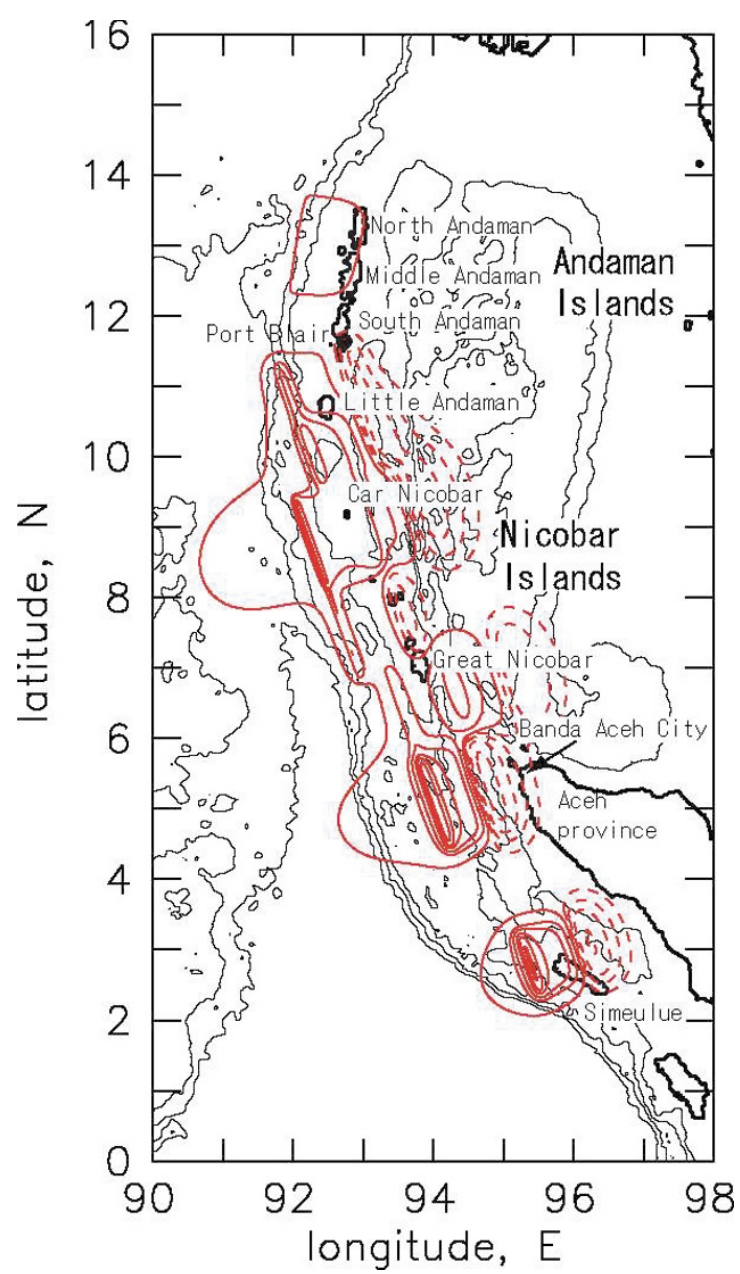

Fig. 8. Vertical displacement calculated from the coseismic slip distribution shown in Table 2 and Fig. 7. Dashed contours show the subsidence of $50 \mathrm{~cm}, 1 \mathrm{~m}, 2 \mathrm{~m}$, and $3 \mathrm{~m}$. Solid contours shows the uplift of $5 \mathrm{~cm}$, $50 \mathrm{~cm}, 1 \mathrm{~m}, 2 \mathrm{~m}, 4 \mathrm{~m}, 6 \mathrm{~m}$, and $8 \mathrm{~m}$.

largest slip of $23 \mathrm{~m}$ is estimated on the subfault C located off the west coast of the Aceh province in Sumatra. This large slip should be responsible for the large tsunami run-up heights of more than $30 \mathrm{~m}$ measured along the west coast of Aceh province (Moore et al., 2005). The large slip of $21 \mathrm{~m}$ is estimated on the subfault A which is located the north of Simeulue Island. The large slip is responsible for the coseismic uplift observed along the northern coast of Simeulue Island. The large slip of $10-15 \mathrm{~m}$ is estimated on the subfaults H, I, and J which are located near Little Andaman and Car Nicobar Inlands. The slip on the subfault $\mathrm{K}$ is $7 \mathrm{~m}$ which was responsible for the coseismic subsidence of $0.9 \mathrm{~m}$ near Port Blair.

\section{Discussion}

The vertical coseismic displacement from the slip distribution estimated from the tsunami waveform inversion is shown in Fig. 8. The observed subsidence of $0.2-0.6 \mathrm{~m}$ in Banda Aceh city is consistent with the computed displacement. The observed subsidence of more than $1 \mathrm{~m}$ near the northwest coast of the Aceh province is also consistent with the computed one. The uplift along the northern coast and the subsidence along the southern coast in Simeulue Island 
are explained by the computed displacement. The subsidence along the coast of the Nicobar Islands is also explained by the computed one except Great Nicobar Island. The observed subsidence of $0.9 \mathrm{~m}$ at the tide gauge in Port Blair is consistent with the computed subsidence of $1.0 \mathrm{~m}$. The uplifts along the North and Middle Andaman Islands are also explained by the computed one. This indicates that the slip distribution estimated from the tsunami waveforms is consistent with the observed coseismic vertical deformation.

The total seismic moment is calculated to be $7.2 \times 10^{22}$ $\mathrm{Nm}(\mathrm{Mw} 9.2)$ by assuming that the rigidity is $5.0 \times 10^{10}$ $\mathrm{N} / \mathrm{m}^{2}$. This seismic moment is consistent with that estimated by Park et al. (2005) using Earth's seismic free oscillation, $6.5 \times 10^{22} \mathrm{Nm}$. In general, the pattern of the slip distribution estimated in this study is similar to the result estimated using seismic waves by Ammon et al. (2005). In detail, the differences between two results exist. Especially, the slip amount of 20-23 m estimated off northern Sumatra Island in this study is larger than that of 10-15 m estimated using seismic waves by Ammon et al. (2005). Because very large run-up tsunami heights of more than $30 \mathrm{~m}$ were reported along the west coast of Aceh province, additional slip, which did not excite seismic waves efficiently, might occur in this region during the 2004 SumatraAndaman earthquake. This is still speculation, and further investigations in future are necessary.

\section{Conclusions}

The average rupture speed of the 2004 SumatraAndaman earthquake is estimated to be $1.7 \mathrm{~km} / \mathrm{s}$ from tsunami waveform analysis. The rupture of the earthquake extends about $1200 \mathrm{~km}$ toward north-northwest along the Andaman trough. The largest slip of $23 \mathrm{~m}$ is estimated off the northwest coast of the Aceh province in Sumatra, Indonesia. This large slip should be responsible for the catastrophic tsunami along the northwest coast of Sumatra. The total seismic moment is calculated to be $7.2 \times 10^{22} \mathrm{Nm}$ (Mw 9.2) which is similar to the other studies using seismic waves (Park et al., 2005; Ammon et al., 2005).

Acknowledgments. We thank Dr. Nanang T. Puspito and two anonymous reviewers for comments and suggestions that improved our manuscript. This work was supported by Special Coordination Funds for Promoting Science and Technology, by Ministry of Education, Sports, Culture, Science and Technology (MEXT).

\section{References}

Ammon, J. C., C. Ji, H. Thio, D. Robinson, S. Ni, V. Hjorleifsdottir, H. Kanamori, T. Lay, S. Das, D. Helmberger, G. Ichinose, J. Polet, and D. Wald, Rupture process of the 2004 Sumatra-Andaman earthquake, Science, 308, 1133-1139, 2005.

Johnson, J. M., Heterogeneous coupling along Alaska-Aleutians as inferred from tsunami, seismic, and geodetic inversions, Advance in Geophysics, 39, 1-110, 1998.

Kaystrenko, V., N. Razzigaeva, Y., Korolev, N. Polukhin, A. Zaytsev, G. S. Prasetya, and R. Hidayat, Manifestation of the Indian Ocean Earthquake and Tsunami of December 26, 2004 in the near Epicenter zone (Simeulue Is.) and near Belawan Port on the NE Coast of the Sumatra Is., Earth Planets Space, 2006 (submitted).

Kawata, Y., Y. Tsuji, Y. Sugimoto, H. Hayashi, H. Matsutomi, Y. Okamura, I. Hayashi, H. Kayane, Y. Tanioka, K. Fujima, F. Imamura, M. Matsuyama, T. Takahashi, N. Maki, and S. Koshimura, Comprehensive analysis of the damage and its impact on coastal zones by the 2004 Indian Ocean tsunami disaster, Research Report of Grants-in-Aid for Special Purposes in Japan Society for the Promotion of Science (\#16800055), in press.

Lay, T., H. Kanamori, C. J. Ammon, M. Nettles, S. N. Ward, R. C. Aster, S. L. Beck, S. L. Bilek, M. R. Brudzinski, R. Butler, H. R. Deshon, G. Ekstrom, K. Satake, and S. Sipkin, The great Sumatra-Andaman earthquake of 26 December 2004, Science, 308, 1127-1132, 2005.

Malik, J. and C. V. R. Murty, Signatures of land-level changes in Andaman and Nicobar Islands (India) due to M 9.3 Sumatra earthquake of 26 December 2004, Abstract for the AOGS 2005 annual meeting, S32/3A01-7/202, 2005

Moore, A., Y. Nishimura, G. Gelfenbaum, T. Kamataki, and R. Triyono, Sedimentary deposits of the 26 December 2004 tsunami on the northwest coast of Aceh, Indonesia, Earth Planets Space, 58, this issue, 253258, 2006.

Okada, Y., Surface deformation due to shear and tensile faults in a halfspace, Bull. Seismol. Soc. Am., 75, 1135-1154, 1985.

Park, J., T. A. Song, J. Tromp, E. Okal, S. Stein, G. Roult, E. Clevede, G. Laske, H. Kanamori, P. Davis, J. Berger, C. Braitenberg, M. V. Camp, X. Lei, H. Sun, H. Xu, and S. Rosat, Earth's free oscillations excited by the 26 December 2004 Sumatra-Andaman earthquake, Science, 308, 1139-1144, 2005.

Satake, K., Inversion of tsunami waveforms for the estimation of heterogeneous fault motion of large earthquakes: The 1968 Tokachi-oki and the 1983 Japan Sea earthquakes, J. Geophys. Res., 94, 5627-5636, 1989.

Tanioka, Y. and K. Satake, Coseismic slip distribution of the 1946 Nankai earthquake and aseismic slips caused by the earthquake, Earth Planets Space, 53, 235-241, 2001.

Tichelaar, B. W. and L. J. Ruff, How good are our best model? Jackknifing, bootstrapping, and earthquake depth, EOS, 70, 593, 605-606, 1989.

Tobita, M., M. Kaizu, M. Murakami, M. Tsuzawa, T. Imakiire, H. Yarai, H. Suito, Y. Fukuzaki, M. Kato, S. Fujiwara, A. Itabashi, and H. Nakai, Coastline change and tsunami inundation area of Northern Sumatra Island inferred from satellite synthetic aperture radar images, Abstract for the 2005 Japan Earth and Planetary Science Joint meeting, J113$009,2005$.

Y. Tanioka (e-mail: tanioka@eos.hokudai.ac.jp), Yudhicara, T. Kususose, S. Kathiroli, Y. Nishimura, S. Iwasaki, and K. Satake 